\title{
Osong, Value Transformation of Oral Tradition in Regional Language Learning of SMPN 1 Bulupoddo, Sinjai Regency
}

\author{
Hardianti Hasyim ${ }^{1}$, Ery Iswary ${ }^{2}$, Ilham ${ }^{3}$, Firman Saleh ${ }^{4}$ \\ 1) 2) 3) 4) Hasanuddin University \\ 1) hardiantihasyim.panampa@gmail.com \\ 2) ery.iswary@gmail.com \\ 3) ilhamdaengmakkelo@gmail.com \\ 4) firmansalehsastraarea@unhas.ac.id
}

\begin{abstract}
This study is a quantitative descriptive study that describes the ability to read blanks of eighth-grade students of SMPN 1 Bulupoddo, Sinjai Regency. Based on the presentation of the results of the data analysis above, it can be described in detail about the osong reading ability of the eighth-grade students of SMPN 1 Bulupoddo, Sinjai Regency. Students' test results in reading blanks are then analyzed based on predetermined criteria or assessment indicators, namely the pronunciation aspect with a score of 1 to 1 , intonation aspect with a score of 1 to 3, gesture aspect with a score of 1 to 3, expression aspect with a score of 1 up to 3, the aspect of appreciation with a score of 1 to 3 , the aspect of appearance with a score of 1 to 3 . Of the six aspects of the assessment of reading blanks, the maximum score is 18. In the contents of elong osong itself, the theme contained in it is the figure of a Bugis human who is brave and does not stand still and becomes a coward towards the nation and homeland. The tones used are generally satirical and patronizing. The atmosphere or state of the reader's soul after reading or listening to the osong can be a booster or an incendiary. While the results of the current study emphasize the ability of students to read blanks. This is what distinguishes previous research from the results of the present study.
\end{abstract}

Keywords: Osong, Value Transformation, Learning, Regional Language, Sinjai

\section{INTRODUCTION}

Oral literature, according to Udin (1996), is a set of oral narrative performances that involve speakers and audiences according to the procedures and traditions of the performance. Oral literature is also in the form of word of mouth, and its contents can be known through speech. Furthermore, oral literature (Nisya, 2013) is a literary work circulating in the community or passed down from generation to generation in oral form. Oral literature is difficult to know who the original speaker or the origin of the first author is because it is in the form of speech which at any time in the narrative process is easy to change names or is easily instigated.

According to Waluyo (2003: 44), poetry appreciation relates to activities related to 
poetry, namely listening or reading poetry with appreciation, writing poetry, and writing poetry reviews. Poetry appreciation is an appreciation for poetry as a result of the introduction, understanding, interpretation, appreciation, and enjoyment of literary works supported by inner sensitivity to the values contained in poetry.

In order for poetry learning to lead to appreciation, poetry learning should pay attention to the concepts: (1) poetry learning should not lead to knowledge of poetry theory, (2) poetry learning must involve students directly in the appreciating process, teachers should provide opportunities for students to get their own enjoyment and benefits from reading poetry, and (4) learning is directed at acquiring inner experiences within students that they gain from the process of reading poetry, recognizing, understanding, appreciating, assessing, and finally appreciating literary works.

Learning is a teaching and learning process that leads to the achievement of the desired goals. The purpose of learning each subject in schools, in general, is to prepare students to be able to live in their communities as useful human beings, namely having knowledge and skills in overcoming the problems they face. In the teaching and learning process, there must be elements supporting the learning system, at least consisting of students, a goal, and work procedures to achieve the desired goal. To achieve this goal, it is necessary to have teaching and learning motivation from both the teacher and students, teaching materials, the availability of supporting media, and the use of an approach that is easy to follow and understand by students.

The provision of teaching materials that are in accordance with the needs of students and the wider community, maintaining good quality and quality, and using the right approach will ensure the achievement of learning objectives (Gino, et al., 2000: 18-33). Another learning goal is to instill character values in students through the devices that exist within the institution. Changes in values in Indonesian society today tend to increasingly lead to a decline in ethics and morals. This condition has reached an alarming level. Various stories through the mass media, both print and electronic, illustrate the prevalence of immoral, immoral, criminal, and even brutal acts.

This indicates that this behavior is further away from the noble values that are the nature and soul of the Indonesian people, who are known for their superior culture (Sasongko, 2003: 1). This is what makes the importance of inculcating noble values in the soul of the Indonesian nation (especially students). All the substance of learning material, whether general, social, even natural knowledge (exact), is also expected to be able to develop the nuances of inculcating character and personality. The learning materials closest to the development of character and personality are none other than language and literature. However, it cannot be denied that language and literature learning has been focused more on practical and pragmatic 
interests, namely to improve communication fluency and scientific deepening. Therefore,

These noble values are actually more imposed on the literary field, as evidenced by the number of literary works, literary studies, essays in the form of volumes, and essays that have been reprinted and published by the government in order to achieve this goal. The government's efforts show how important it is to learn literary appreciation. In addition to being enjoyed, internalized, and influential in everyday life, it turns out that the results of learning literary appreciation are more than that. The following can the author express an opinion (Sapari, 2002)

Literature learning is one of the important aspects that need to be taught to students so that they are able to enjoy, appreciate, understand, and utilize literary works to develop personality, broaden life horizons, and improve knowledge and language skills. Literature learning materials in schools have a great influence on students' lives because they can increase students' sensitivity to facts in society, soften students' feelings, and shape their personality and noble character.

Literature appreciation learning that has been carried out so far is monotonous and uninteresting. Students only recognize at a glance about literary works, literary knowledge, and authors of literary works. Students are not invited to understand, let alone enjoy, literary works or have not yet appreciated literature. This is stated (Sawali, 2002)
The echo of the failure of learning literary appreciation in schools has long been heard. Many observers judged that the learning of literary appreciation had been monotonous, uninteresting, and even boring. Students are not invited to explore and associate with the greatness of the values contained in literary texts, but are simply introduced to theoretical and rote knowledge of literature. They are not invited to appreciate (read: understand and enjoy) real literary texts, but simply memorize the names of writers and their works. In other words, what is conveyed by the teacher in learning literature is only the skin, so that students fail to enjoy the "delicious" content and aroma of the value content in literary works.

Such learning conditions are not only apprehensive, but have also "rotted" the process of students' emotional and spiritual intelligence. Literature appreciation learning has not been delivered or taught optimally by Indonesian language and literature teachers, making students' appreciation power and interest in learning literary appreciation not developed. Whereas appreciating literary works is an activity that students need to do to appreciate students' thoughts and feelings. Learning appreciation of literature should be a fun learning and invite students to appreciate thoughts and feelings through literature.

This was stated by Hamzah (2003: 18-19) that teachers are less interested in literary appreciation activities so that literary appreciation learning tends to be monotonous 
and does not vary. Teachers are not motivated to be creative in the learning. Learning appreciation of literature seems boring and does not attract students. Supported by students' reading interest in literary works is low, facilities and infrastructure are inadequate, for example a library that does not collect literary books and there is no interesting literary appreciation learning media.

Osong is one of the results of the Bugis regional literature that expresses the results of creativity and a reflection of society. Regional culture that is widespread in several regions of Indonesia is one aspect of supporting national culture. The culture varies according to the background of life and is a manifestation of all the activities of the community of its adherents, both outwardly and inwardly. Outer culture is culture whose form can be seen, while inner culture is intangible or not abstract.

Osong is a result of old literature that has existed in society since ancient times until now. Osong needs to be studied carefully and indepth both in terms of appreciation and content of the work. The form can be classified as regional poetry. The presence of osong is one of the works of Bugis literature that reflects the ideas, ideas, attitudes, and mindsets, as well as the imaginative experiences of the supporting community. By looking at a poetry text, we can see that community activities cannot be separated from the culture of the community itself. In this case, osong can be considered as a work of Bugis literature that can reflect the actions and behavior patterns of the Bugis people.

Bugis poetry is a literary work of Bugis people who have been in the midst of Bugis society since the past. Bugis poetry has characteristics or conditions that need to be known and considered. To understand the meaning of poetry, special knowledge is needed because it has certain characteristics and conditions as well as introduction in poetry itself. This is also explained (Punagi, 1986: 4) which states that our ability to understand the meaning of poetry is closely related to our ability to see, hear, sounds, and feelings described in poetry.

The ability to appreciate osong in students is important in language teaching, especially in mastering poetry. Osong is a result of old literature that has existed in the community since ancient times until now. Osong needs to be studied carefully and in-depth both in terms of appreciation and content of the work. The form can be classified as regional poetry. The presence of osong is one of the works of Bugis literature that reflects the ideas, ideas, attitudes and mindsets, as well as the imaginative experiences of the supporting community.

Osong as a means to convey ideas, ideas, attitudes and patterns of thought and behavior in accordance with the intent and purpose of the wearer, these forms are an interesting thing to study. The intentions and thoughts and feelings conveyed in the osong are stated indirectly by the user community. The meaning is implied in 
the language and how to appreciate it. From the results of the student's blank reading, an analysis will be carried out. Furthermore, from the results of the analysis, the findings will be known, namely whether students are able or not to appreciate osong.

Literary works that use beautiful and meaningful words. Poetry has the following characteristics: Prioritizing beauty and prioritizing the beauty of language. The language used is concise and connotative, presented in the form of a monologue. According to (Rosyanti, 2012) a poem includes the following elements:

1. Diction means that the choice of words in poetry is connotative so that the meaning may be more than one beautiful sound and usually has harmony with other words.

2. Imagination, is a word or arrangement of words that can cause service or imagination so that the reader feels as if he heard or saw something that was expressed by the poet.

3. Access, is an expression sentence that states something by comparing it with other objects or words.

4. Rhyme, is the repetition of sound, repetition of words or sentences in poetic stanzas.

5. Biographical typography, or the form of writing in poetry, is different from other essays. Poetry is made up of stanzas and lines. In contemporary poetry by Calzoum Bachri, typography is considered so important that it shifts the magnetic position of the meaning of the words in the poem.

6. Typography has its own meaning that can be interpreted reading elements of poetry.

7. The contents of the poem include: Elements of the theme, the theme is the main idea expressed by the poet in his poem which serves as the main basis for the poet in writing poetry of feelings. Poetry is a literary work that best represents the poet's feelings

8. Tone and atmosphere do not mean the attitude of the poet. Reading the atmosphere is the state of the soul of the reader in reading poetry. The atmosphere is the effect that the poem has on reading.

9. The mandate is the message that the poet wants to convey through his poetry, the implied message behind a series of words can also be behind the theme.

The characteristics of oral literature according to (Rusyana, 2014) are as follows:

1. Oral literature depends on speakers, listeners, space and time.

2. Anonymous.

3. Oral literature is a literary text that is spoken orally.

4. There is physical contact between the speaker and the listener.

5. Oral literature has its own conventions and poetics.

6. Oral literature is always present in different versions and variants. 
7. Oral literature has survived traditionally and was disseminated in standard or relative form over a long period of time.

The process in appreciation activities according to (Maedar, et al, 1990: 92) is as follows:

1. Enjoyment stage; Operational actions that occur at this stage are for example watching movies, listening to music, watching dramas, reading novels and so on.

2. award stage; Operational actions that occur at this stage, for example, see the good value or benefits of a literary work.

3. understanding stage; its operational action is to research and analyze the intrinsic and extrinsic elements of a literary work and try to conclude it.

4. appreciation stage; operational action is to further analyze a work, seek the essence or meaning of a literary work and its arguments, make interpretations and formulate opinions based on the analysis that has been made.

5. Application or application stage; operational actions are generating new ideas, practicing inventions or utilizing the results of appreciation in achieving material and spiritual values for social, political, and cultural interests.

\section{METHODS}

The technique used to collect data in this study is an oral test technique. The tests that are tested on students are by assigning students to read blanks in front of the class in turns with a time of 3 minutes/person documented by video. The steps taken in data collection are as follows:

1. Explain to students about aspects that must be considered in reading blanks.

2. Students are assigned to read blanks one by one in front of the class by paying attention to aspects of reading blanks.

3. Giving a score for the blank reading test

In this study, the data collected will be analyzed using descriptive statistical techniques. The steps to analyze the data are as follows:

\section{Creating a Raw Score List}

The raw score is determined based on the aspects assessed in reading poetry. The aspects assessed and their respective weights can be described in the following table:

Table 1. Assessment Criteria for Reading Osong

\begin{tabular}{llr}
\hline No & \multicolumn{1}{c}{ Rated Aspect } & Score \\
\hline \multicolumn{1}{l}{ Pronunciation } & 3 \\
& a. pronunciation (vocals and consonants) is quite clear in reading poetry & 2 \\
b. pronunciation (vocals and consonants) is not clear in reading contents & 1 \\
c. pronunciation (vocals and consonants) is not clear in reading poetry &
\end{tabular}




\begin{tabular}{llc}
\hline No & \multicolumn{1}{c}{ Rated Aspect } & Score \\
\hline & Intonation & 3 \\
2 & $\begin{array}{l}\text { a. proper and regular intonation in accordance with the rhyme of the poem read } \\
\text { b. the intonation is not precise and irregular with the rhyme of the poem that is read }\end{array}$ & 2 \\
c. Incorrect and irregular intonation with the rhyme of the poem that is read & 1 \\
\hline Gesture & 3 \\
a. gestures that support poetry reading & 2 \\
b. gesture which not supportive in reading poetry & 1 \\
\hline
\end{tabular}

\begin{tabular}{ll}
\hline Expression & 3 \\
4 & $\begin{array}{l}\text { a. expression face that supports in reading poetry } \\
\text { b. expression unsupportive face in reading poetry }\end{array}$ \\
c. expression a face that is not cloudy in reading poetryi & 2 \\
\hline
\end{tabular}

Appreciation

5 a. full of appreciation in reading poetry

b. lack of appreciation in reading poetry 2

c. there is no appreciation in reading poetry 1

\begin{tabular}{ll}
\hline Appearance & 3 \\
6 a. appearance is quite supportive in reading poetry & 2 \\
b. appearance is not supportive in reading poetry & 1 \\
c. appearance does not support poetry reading & 1 \\
\hline
\end{tabular}

Maximum Score

(Adopted from Djumingin, 2010)

\section{Giving Interpretation}

To assess the results of the study, it is necessary to provide an interpretation with a range of values of seen in the following table:

Table 2. Interpretation of Value Intervals

\begin{tabular}{ccl}
\hline No & Value Interval & \multicolumn{1}{c}{ Mastery Level } \\
\hline 1 & $85-100$ & Very well \\
\hline 2 & $75-84$ & Well \\
\hline 3 & $65-74$ & Enough \\
\hline 4 & $55-64$ & Not enough \\
\hline 5 & $<54$ & Not much \\
\hline
\end{tabular}

(Nurgyantoro, 2009: 253)

\section{Creating a Frequency Distribution from Raw Score}

The test data obtained from the students' work is still in a state of uncertainty. To find the analysis, it is necessary to arrange a frequency distribution that can facilitate further calculations.

\section{Calculating Student Ability Score}

The formula used to calculate the value of individual student abilities proposed by (Purwanto, 2012: 112)

$$
S=\frac{R}{N} \times 100
$$

Information :

$$
\begin{array}{ll}
\mathrm{S} & : \text { Value searched } \\
\mathrm{R} & : \text { Raw score obtained } \\
\mathrm{N} & : \text { Overall score } \\
100 & : \text { Fixed Value }
\end{array}
$$




\section{Finding the Percentage of Students' Average Ability}

To calculate the percentage of students' average ability classically, the formula proposed by (Aqib et al, 2010: 41) is as follows:

$$
T B K=\frac{N}{S N} \times 100 \%
$$

Information:

TBK : Completed Classical Learning

$\mathrm{N}$ : Many students who get a minimum score of 75

SN : Number of Students

\section{Creating a Classification Table of Student Abilities}

The level of osong reading ability refers to the ability, namely that individually students are considered capable individually if the student's mastery is at least 75 based on the Minimum Completeness Criteria (KKM) at SMPN 1 Bulupoddo, Sinjai Regency. This can be seen in the table below:

Table 3. Classification of Student Ability

\begin{tabular}{cccc}
\hline Score & $\begin{array}{c}\text { Ability } \\
\text { Category }\end{array}$ & Frequency & Percentage \\
\hline $\begin{array}{l}75 \text { and } \\
\text { above }\end{array}$ & Capable & $\ldots \ldots \ldots . .$. & $\ldots \ldots . .$. \\
\hline Under 75 & Not capable & $\ldots . . . . .$. & $\ldots \ldots . .$. \\
\hline
\end{tabular}

From the data source: Administration of SMPN 1 Bulupoddo, Sinjai Regency, 2015/2016 Academic year

Students are said to be capable if they have mastery of $85 \%$ of the total number of sample students who score 75 and above. On the other hand, it is said to be unable if less than $85 \%$ of the total number of sample students scores below 75 .

\section{FINDING AND DISCUSSION}

The results of this study were obtained from a reading ability test of eighth-grade students of SMP Negeri 1 Bulupoddo, Sinjai Regency. The results of this study are the results of quantitative descriptive research, namely the results of data analysis using numbers. The numbers are described to describe the students' ability to read blanks. The results of reading blanks are used as data that will be described in this section. The data is processed and analyzed according to the techniques and procedures described in chapter III.

Data in the form of raw scores from the test results of 20 students who were sampled sequentially from 01 to 20 . To determine the osong reading ability of class VIII students of SMPN 1 Bulupoddo, Sinjai Regency, first explained the osong reading ability based on the assessment.

Osong is one of the results of the literature of the Bugis area which expresses the results of creativity and reflection of society. Regional culture that is widespread in several regions of Indonesia is one aspect of supporting national culture. The culture varies according to the background of life and is a manifestation of all the activities of the community of its adherents, both outwardly and inwardly. Outer culture is culture whose form can be seen, while inner culture is intangible or not abstract.

Osong is a result of old literature that has existed in society since ancient times until now. Osong needs to be studied carefully and in depth 
both in terms of appreciation and content of the work. The form can be classified as regional poetry. The presence of osong is one of the works of Bugis literature that reflects the ideas, ideas, attitudes, and mindsets, as well as the imaginative experiences of the supporting community. By looking at a poetry text, we can see that community activities cannot be separated from the culture of the community itself. In this case, osong can be considered as a work of Bugis literature that can reflect the actions and behavior patterns of the Bugis people.

Bugis poetry is a literary work of Bugis people who have been in the midst of Bugis society since the past. Bugis poetry has characteristics or conditions that need to be known and considered. To understand the meaning of poetry, special knowledge is needed because it has certain characteristics and conditions as well as introduction in poetry itself. This is also explained (Punagi, 1986: 4) which states that our ability to understand the meaning of poetry is closely related to our ability to see, hear, sounds and feelings described in poetry.

A recapitulation of the osong reading ability of eighth grade students of SMPN 1 Bulupoddo, Sinjai Regency on aspects of pronunciation, intonation, gestures, expression, appreciation, and appearance. The recapitulation of data on the ability to read blanks can be seen in table 1 below.

Table 4. Recapitulation of Students' Ability in Each Aspect in Reading Osong

\begin{tabular}{|c|c|c|c|c|c|c|c|c|c|}
\hline \multirow{2}{*}{ No } & \multirow{2}{*}{$\begin{array}{l}\text { Value } \\
\text { Interval }\end{array}$} & \multicolumn{6}{|c|}{ Frequency of Each Aspect in Blank Reading } & \multirow{2}{*}{ Amount } & \multirow{2}{*}{ Average } \\
\hline & & plf & int & gst & ex & phy & pnp & & \\
\hline 1 & $85-100$ & 1 & 2 & 2 & 1 & 2 & 4 & 12 & 2 \\
\hline 2 & $75-84$ & - & 1 & 1 & 2 & - & 1 & 5 & 0.8 \\
\hline 3 & $65-74$ & 14 & 3 & 2 & 1 & 1 & - & 21 & 3.5 \\
\hline 4 & $55-64$ & - & - & & - & - & - & - & - \\
\hline 5 & $<54$ & 5 & 14 & 15 & 16 & 17 & 15 & 82 & 13.7 \\
\hline
\end{tabular}

Information,

$$
\begin{aligned}
& \text { plf : pronunciation } \\
& \text { int : intonation } \\
& \text { gst : gesture } \\
& \text { ex : expression } \\
& \text { phy : appreciation } \\
& \text { pnp : appearance }
\end{aligned}
$$

Based on Table 1, it can be explained that there are 20 samples of the recapitulation of the reading ability of the eighth-grade students of SMPN 1Bulupoddo, Sinjai Regency. The score interval of $85-100$ is 12 with an average of 2 at the very good level of mastery, the interval value of 75-84 is obtained by the number of 5 with an average of 0.8 at the good level of mastery, the interval value of $65-74$ is obtained by the number of 21 with an average of 3.5 at the level of sufficient mastery, and the value interval of 
$<54$ obtained a total of 82 with an average of

13.7 at The level of mastery is less.

Table 5. Recapitulation of Frequency and Percentage of Values above 75 and below 75 Each Aspect in Reading Blank

\begin{tabular}{cccccc}
\hline No & Aspects of reading Osong & $\begin{array}{c}\text { Value } \\
\text { above 75 }\end{array}$ & Percentage & $\begin{array}{c}\text { Value } \\
\text { below 75 }\end{array}$ & Percentage \\
\hline 1 & Pronunciation & 1 & $5 \%$ & 19 & $95 \%$ \\
\hline 2 & Intonation & 3 & $15 \%$ & 17 & $85 \%$ \\
\hline 3 & Gesture & 3 & $15 \%$ & 17 & $85 \%$ \\
\hline 4 & Expression & 3 & $15 \%$ & 17 & $85 \%$ \\
\hline 5 & Appreciation & 2 & $10 \%$ & 18 & $90 \%$ \\
\hline 6 & Appearance & 5 & $25 \%$ & 15 & $75 \%$ \\
\hline
\end{tabular}

Based on table 2, it can be explained that the recapitulation of the frequency and percentage of students' scores in reading blanks is 20 samples. Students are categorized as unable to read osong in the aspect of pronunciation because out of 20 students, only 1 person (5\%) got a score of 75 and above. Students are categorized as unable to read blanks on the intonation aspect because of the 20 samples, only 3 samples (15\%) scored 75 and above. In the aspect of gestures, students' ability to read blanks is categorized as incapable because of the 20 students only 3 samples (15\%) scored 75 and above. In the aspect of expression, students' ability to read blanks was categorized as poor because of the 20 students, only 3 samples (15\%) scored 75 and above. In terms of appreciation, students' ability to read blanks was categorized as poor because of the 20 students, only 2 samples (10\%) scored 75 and above. Then in the aspect of appearance, students' ability to read blanks was categorized as incapable because of the 20 samples, only 5 samples (25\%) scored 75 and above. For more details, it can be seen in the following table of student ability classification.

Table 6. Classification of Student Abilities

\begin{tabular}{ccccc}
\hline No & Score & Freq. & $\%$ & $\begin{array}{c}\text { Ability } \\
\text { Category }\end{array}$ \\
\hline 1 & $\begin{array}{c}75 \text { and } \\
\text { above }\end{array}$ & 3 & $15 \%$ & Capable \\
\hline 2 & Under 75 & 17 & $85 \%$ & Not capable \\
\hline \multicolumn{2}{c}{ Amount } & $\mathbf{2 0}$ & $\mathbf{1 0 0 \%}$ & \\
\hline
\end{tabular}

Based on table 3, it is known that the level of osong reading ability of class VIII SMPN 1 Bulupoddo, Sinjai Regency is categorized as incapable, meaning that it has not reached the predetermined mastery level criteria of $85 \%$. It is proven that out of 20 samples, only 3 people (15\%) got a score of 75 and above, while 17 people (85\%) got a score below 75 .

Based on the presentation of the results of the data analysis above, it can be described in detail about the osong reading ability of the eighth grade students of SMPN 1 Bulupoddo, Sinjai Regency. This study is a quantitative descriptive study that aims to describe the ability 
to read blanks of eighth grade students of SMPN 1 Bulupoddo, Sinjai Regency.

Students' test results in reading blanks are then analyzed based on predetermined criteria or assessment indicators, namely the pronunciation aspect with a score of 1 to 1 , intonation aspect with a score of 1 to 3 , gesture aspect with a score of 1 to 3 , expression aspect with a score of 1 up to 3 , the aspect of appreciation with a score of 1 to 3 , the aspect of appearance with a score of 1 to 3 . Of the six aspects of the assessment of reading blanks, the maximum score is 18.

Osong reading activity is one of the processes or stages of appreciating activities as it has been stated that Osong reading activities are at the enjoyment stage where operational actions that occur at this stage are for example watching movies, listening to music, watching dramas, reading novels and so on.

The inability of students to read the osong of class VIII SMPN 1 Bulupoddo, Sinjai Regency is caused by factors including, firstly, most of the students do not understand Bugis literary works, especially regarding the osong itself and how to read it. Second, some students do not have a Bugis ethnic background, so reading osong sounds stuttering and is considered difficult. Therefore, the solution that can be done is as a teacher should improve literary learning, especially in osong, by training students in reading osong. Furthermore, the teacher must always motivate students to the importance of learning Bugis regional literature.
As for what distinguishes the results of previous studies with the results of research that has been carried out now, the results of previous studies have discussed about osong but more towards the content of elong osong itself, namely the theme contained in it is the figure of a Bugis human who is brave and does not stand idly by and becomes a coward towards the nation and homeland. The tones used are generally satirical and patronizing. The atmosphere or state of the reader's soul after reading or listening to the osong can be a booster or an incendiary. While the results of the current study emphasize the ability of students to read blanks. This is what distinguishes previous research with the results of the present study.

\section{CONCLUSION}

The level of blank reading ability of class VIII SMPN 1 Bulupoddo, Sinjai Regency is categorized as incapable, meaning that it has not reached the predetermined mastery level criteria of $85 \%$. It is proven that out of 20 samples, only 3 people (15\%) got a score of 75 and above, while 17 people (85\%) got a score below 75. In fact, kThe presence of Osong is one of the works of Bugis literature that reflects the ideas, ideas, attitudes, and mindsets, as well as the imaginative experiences of the supporting community. By looking at a poetry text, we can see that community activities cannot be separated from the culture of the community itself. In this case, osong can be considered as a work of Bugis literature that can reflect the 
actions and behavior patterns of the Bugis people.

\section{REFERENCES}

Aminuddin. (2002). Introduction to Appreciation of Literary Works. Bandung: Sinar Baru Algesindo.

Aqib, Zainal, et al. (2010). Classroom Action Research For Teachers. Bandung: Yrama Widya.

Djumingin, Sulastriningsih. (2010). Assessment of Indonesian Language and Literature Assessment. Makassar: Makassar State University Publishing Agency.

Gino, Suwarni, Suripto, Maryanto, and Sutijan. (2000). Learning and Learning I. Surakarta: Ministry of Education and Culture.

Hamza. (2003). The Problems of Teaching Literature in Schools. Horizon Magazine. Skyline,July, Issue 79, p. 18-19

Jamaluddin. (2003). Problematic Learning Language \& Literature. Yogyakarta: Adicita Karya Nusa.

John, Suprihanto, et al. (2003). Organizational Behavior. Organizational behavior. Yogyakarta: YKPN College of Economics.

Kushartanti, et al. (2005). Enchantment of Language: The First Step to Understanding Linguistics. Jakarta: Gramedia Pustaka Utama.

Maedar, et al. (1990). Teaching Appreciation of Literature. Department of Education and Culture.

Mahmud. (1993). Position and Function of Elong Ugi. Edge of View: Islamic Boarding School.

Ministry of National Education. (2006). Graduate Competency Standards for Primary and Secondary Education Units. Jakarta: Ministry of National Education
Nurgyantoro, Burhan. (2009). Assessment in Language and Literature Teaching. Yogyakarta: BPFE

Poerwadaminta, WJS. (1986). General Indonesian Dictionary. Jakarta: Balai Pustaka.

Punagi, Andi. (1986). South Sulawesi Cultural Gift. Ujung Pandang: Cultural Foundation of South Sulawesi.

Purwanto. (2012). Quantitative Research Methodology for Psychology and Education. Yogyakarta: Student Library.

Rosyanti. (2012). Puisi lama. (online)Available

Sasongko, et al. (2003). Environmental Noise. Semarang: Diponegoro University Publishing Agency.

Sawali. (2002). The Autonomy of Literature Teaching. http://www.sma.net.com. Accessed on November 3, 2015, at 15:41 WITA.

Sopiah. (2008). Organizational Behavior. Yogyakarta: Andi.

Tarigan, Thunder Henry. (2008). Reading. Bandung: Space.

Teeuw, A. (1983). Reading and Assessing Literature. Jakarta: Gramedia.

Udin, Syamsuddin. (1996). South Coastal Rebab Malin Kundang. Jakarta: Torch Foundation.

Utami, Maria. (2010). Choosing poetry, Building Character. Semarang: Bandungan Institute.

Wahidji, Abu, et al. (1985). Indonesian Language Skills (Reading and Writing) Grade VI Elementary School Students in the Gorontalo Region. Jakarta: Center for Language Development and Development of the Ministry of Education and Culture.

Waluyo, J Herman. (2003). Poetry Appreciation. Jakarta: Gramedia. 